US Army Corps

of Engineers ${ }_{\circledast}$

Engineer Research and

Development Center

\title{
VI Preferential Pathways of a Large Government Building
}

Jay Clausen. D. Moore, K. Miller, and L. Haines-Ecklund

February 2022 
The U.S. Army Engineer Research and Development Center (ERDC) solves the nation's toughest engineering and environmental challenges. ERDC develops innovative solutions in civil and military engineering, geospatial sciences, water resources, and environmental sciences for the Army, the Department of Defense, civilian agencies, and our nation's public good. Find out more at www.erdc.usace.army.mil.

To search for other technical reports published by ERDC, visit the ERDC online library at https://erdclibrary.on.worldcat.org/discovery. 


\section{Preferential Pathways of a Large Government Building}

Jay Clausen

Cold Regions Research and Engineering Laboratory

U.S. Army Engineer Research and Development Center

72 Lyme Road

Hanover, NH 03775

D. Moore and K. Miller

USACE New England District

Concord, MA 01742

L. Haines-Ecklund

U.S. Army Environmental Command

Fort Sam Houston, TX 78234

Final report

Approved for public release; distribution is unlimited.

\footnotetext{
Prepared for U.S. Army Environmental Command Fort Sam Houston, TX 78234

Under MIPR Customer Order 11415853
} 


\section{Preface}

This study was conducted for the U.S. Army Corps of Engineers (USACE) under IMCOM-WEST, Fort Sam Houston, MIPR Customer Order 11415853. The technical monitor was Dr. J ay Clausen.

The work was performed by the Biogeochemical Sciences Branch (Mr. Nathan Lamie, Chief) of the of the Research and Engineering Division (Dr. George Calfas, Chief), U.S. Army Engineer Research and Development Center, Cold Regions Research Engineering Laboratory (ERDCCRREL); the USACE New England District; and the U.S. Army Environmental Command. At the time of publication, the deputy director for ERDC-CRREL was Mr. Bryan E. Baker and the director was Dr. J oseph Corriveau.

This material was originally presented on 21 October 2021 at the Association for Environmental Health and Sciences Foundation (AEHS) virtual 37th Annual International Conference on Soils, Sediments, Water, and Energy.

COL Teresa A. Schlosser was the commander of ERDC and the director was Dr. David W. Pittman.

DISCLAIMER: The contents of this report are not to be used for advertising, publication, or promotional purposes. Citation of trade names does not constitute an official endorsement or approval of the use of such commercial products. All product names and trademarks cited are the property of their respective owners. The findings of this report are not to be construed as an official Department of the Army position unless so designated by other authorized documents. 


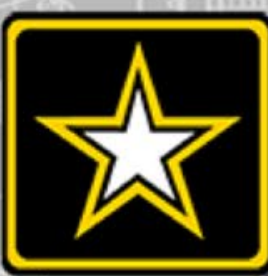

U.S.ARMY

VI PREFERENTIAL PATHWAYS OF A LARGE GOVERNMENT BUILDING

Prepared by Jay Clausen, ERDC-CRREL

Cold Regions Research and Engineering Laboratory, BSB

D. Moore, K. Miller, USACE NAE

L. Haines-Ecklund (USAEC)

21 October 2021

Approved for public release: Distribution is unlimited

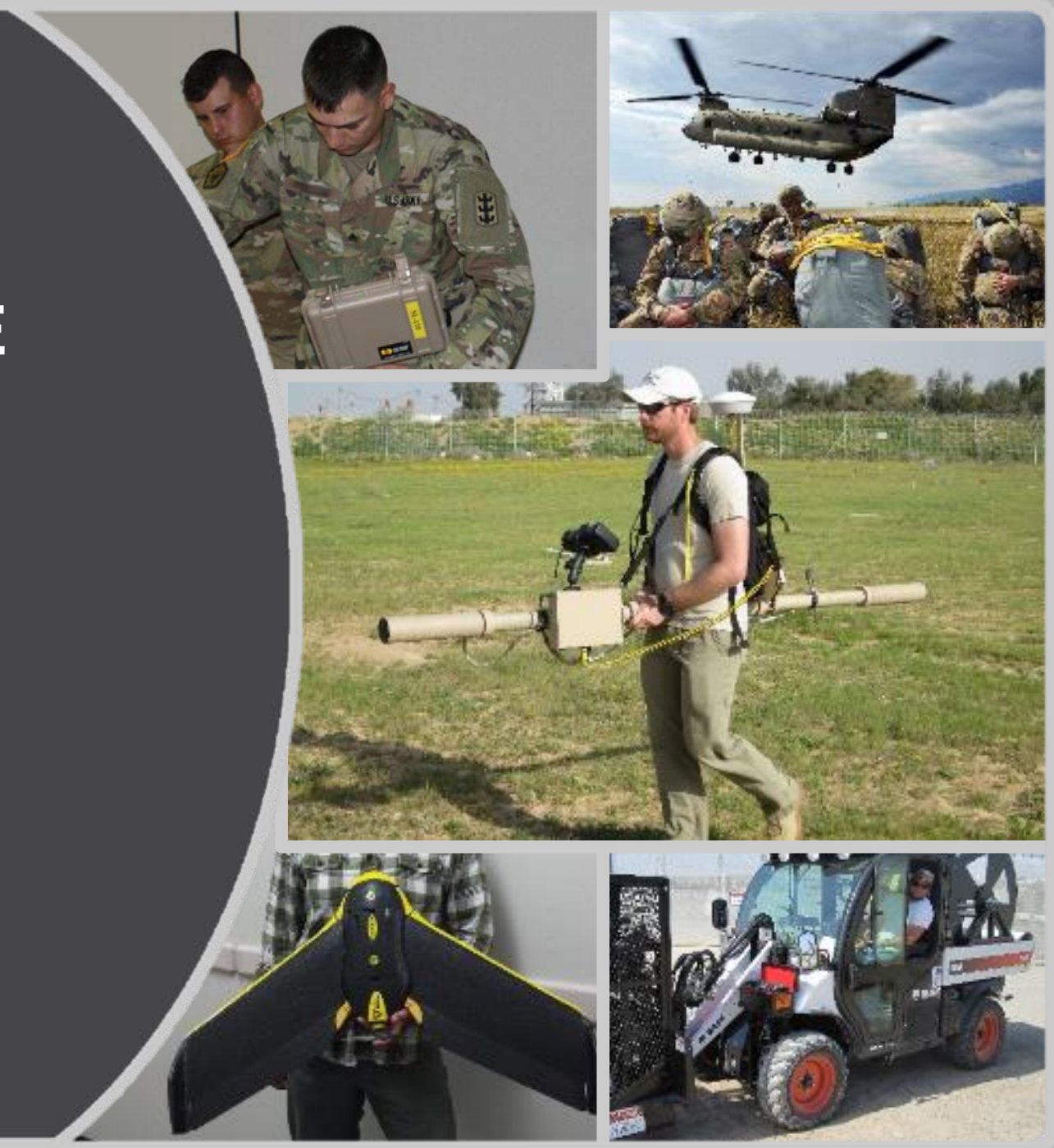




\section{Acknowledgements}

- Terry Harwood (USACE ERDC-CRREL)

- Dan Groher (USACE NAE)

- Dave Becker (USACE EMCX)

- Jack Besse, Scott Calkin, Rod Rustad, Jeffrey Picket, Glen Gordon, Wolfgang Calicchio (Wood PIc) 


\section{Background}

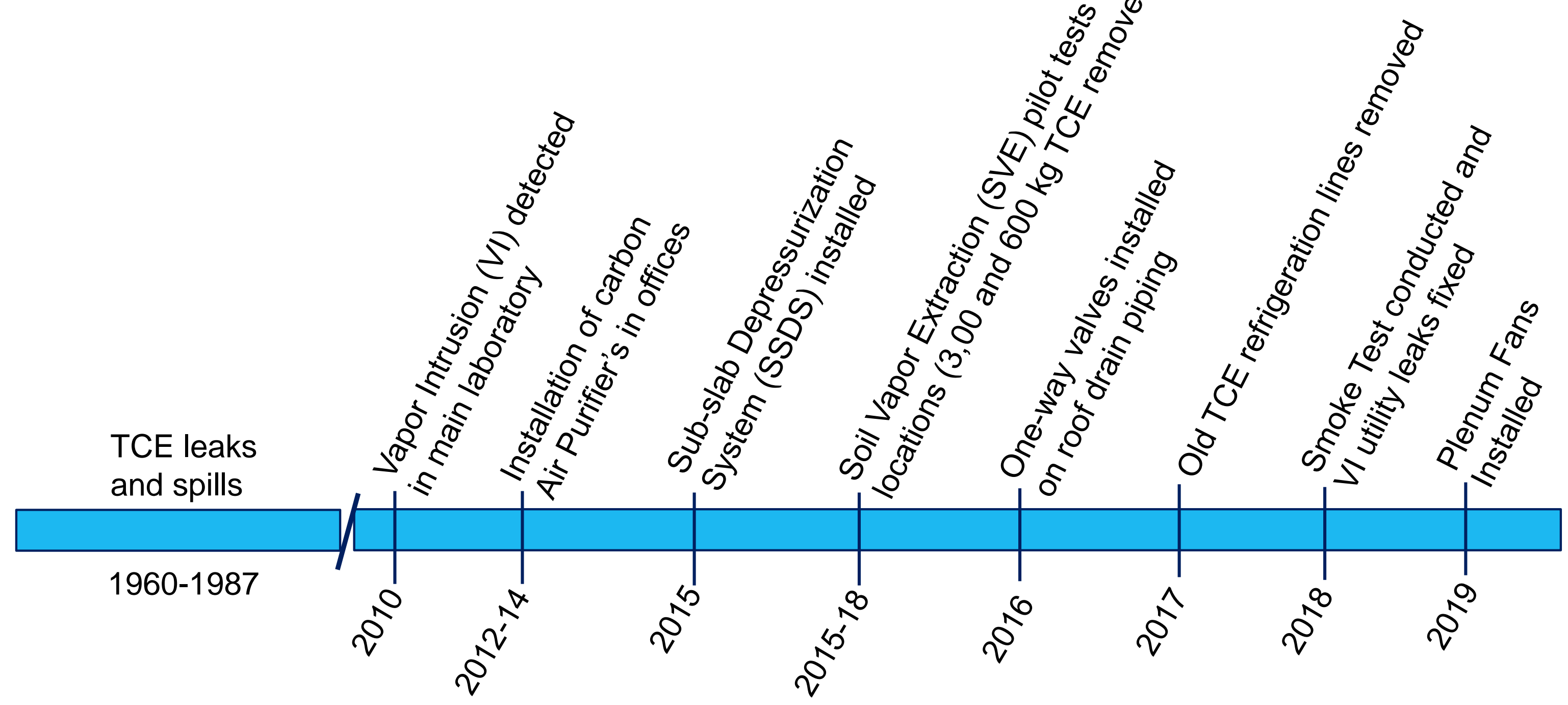




\section{Pre-Remedial Contaminant Distribution}

In and Around Main Laboratory

- Subsurface soil gas TCE concentrations in excess of $10,000,000 \mathrm{ug} / \mathrm{m}^{3}$

- Sub-slab TCE concentrations up to 5,900,000 $\mu \mathrm{g} / \mathrm{m}^{3}$

- Indoor air sub-basement TCE concentrations, 25 to $91 \mu \mathrm{g} / \mathrm{m}^{3}$

- Indoor air basement TCE concentrations, 15 to $241 \mu \mathrm{g} / \mathrm{m}^{3}$

- Indoor air $1^{\text {st }}$ floor TCE concentrations, 0.86 to $4.7 \mu \mathrm{g} / \mathrm{m}^{3}$

- Indoor air $2^{\text {nd }}$ floor TCE concentrations, 2.5 to $48 \mu \mathrm{g} / \mathrm{m}^{3}$

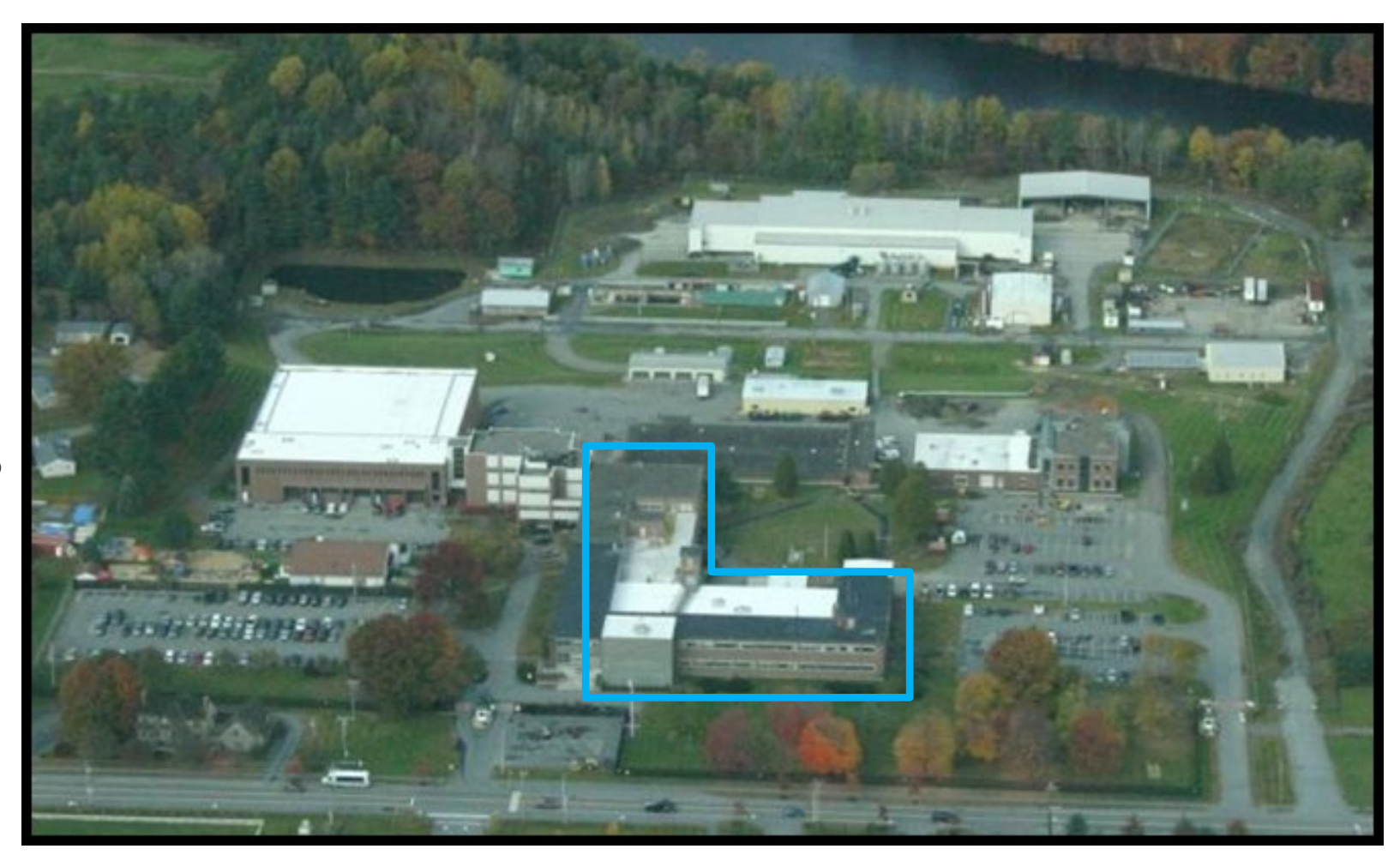




\section{Sub Slab Depressurization (SSDS)}
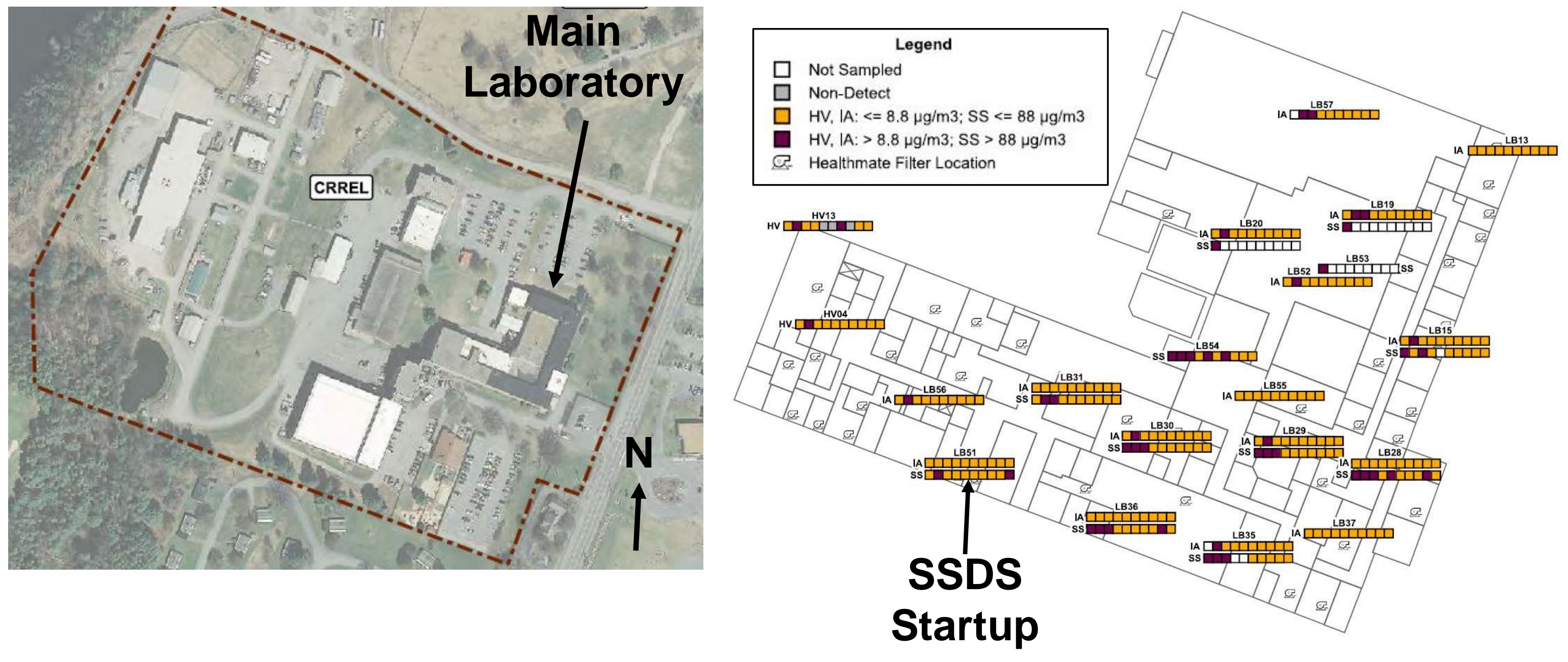

US Army Corps of Engineers • Engineer Research and Development Center 


\section{TCE Levels Second Floor}

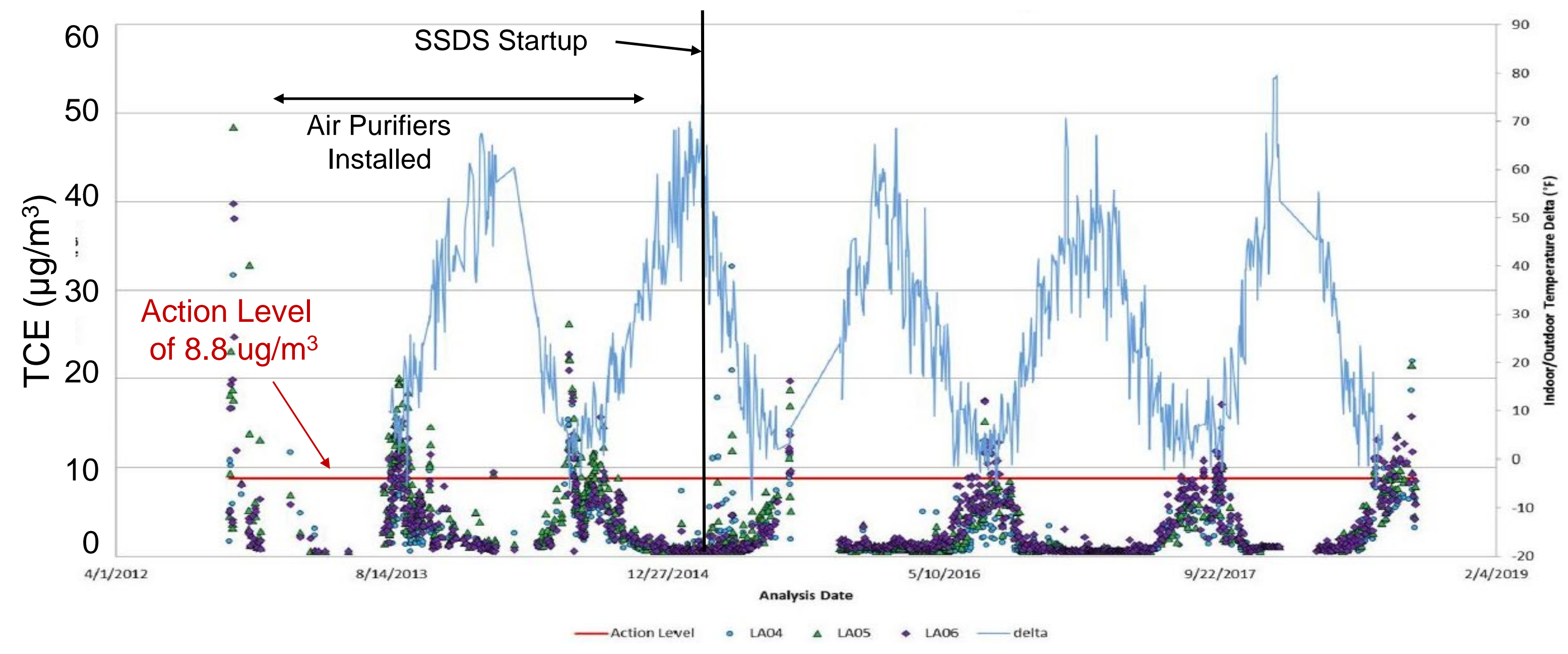




\section{Soil Vapor Extraction Impacts on Subslab Vapor}

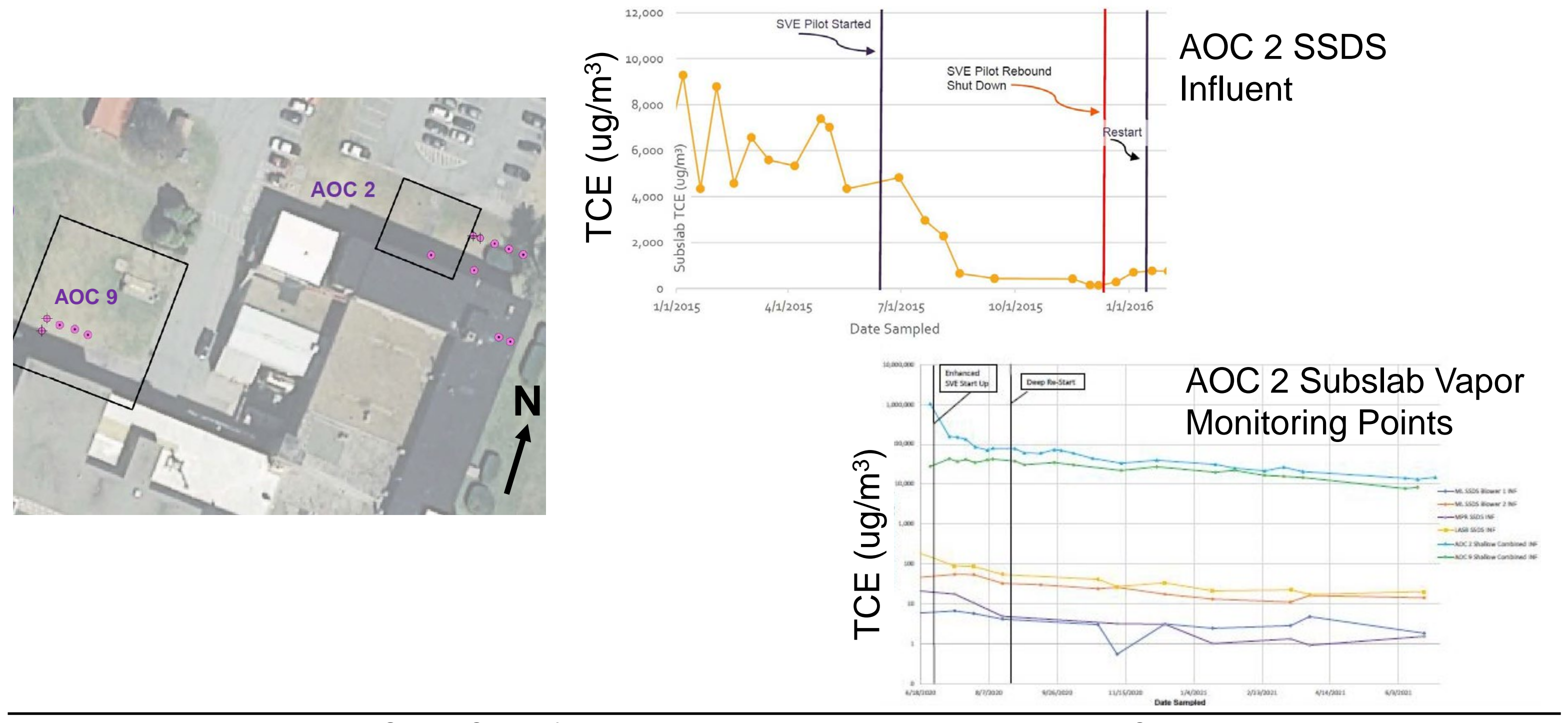




\section{Soil Gas Levels}

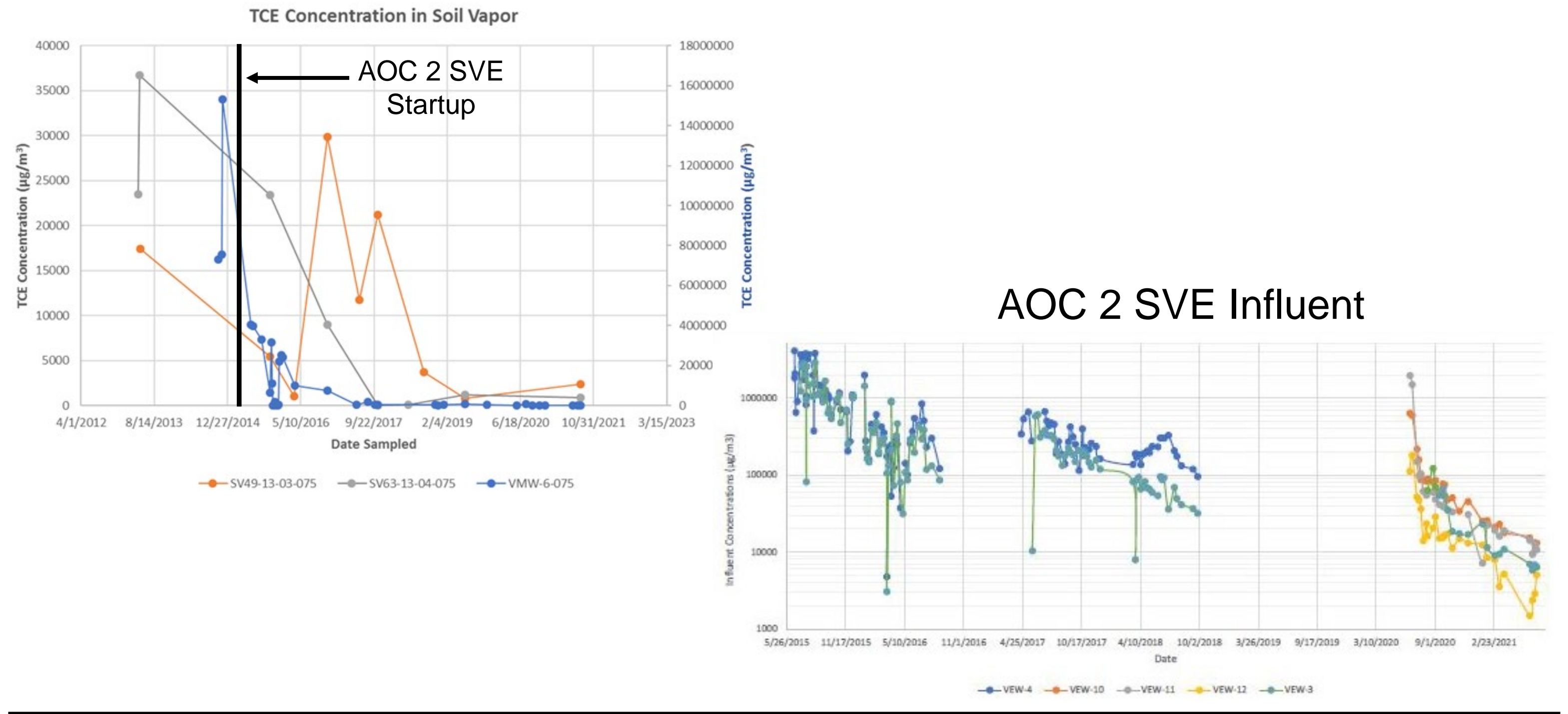


TCE Levels Second Floor

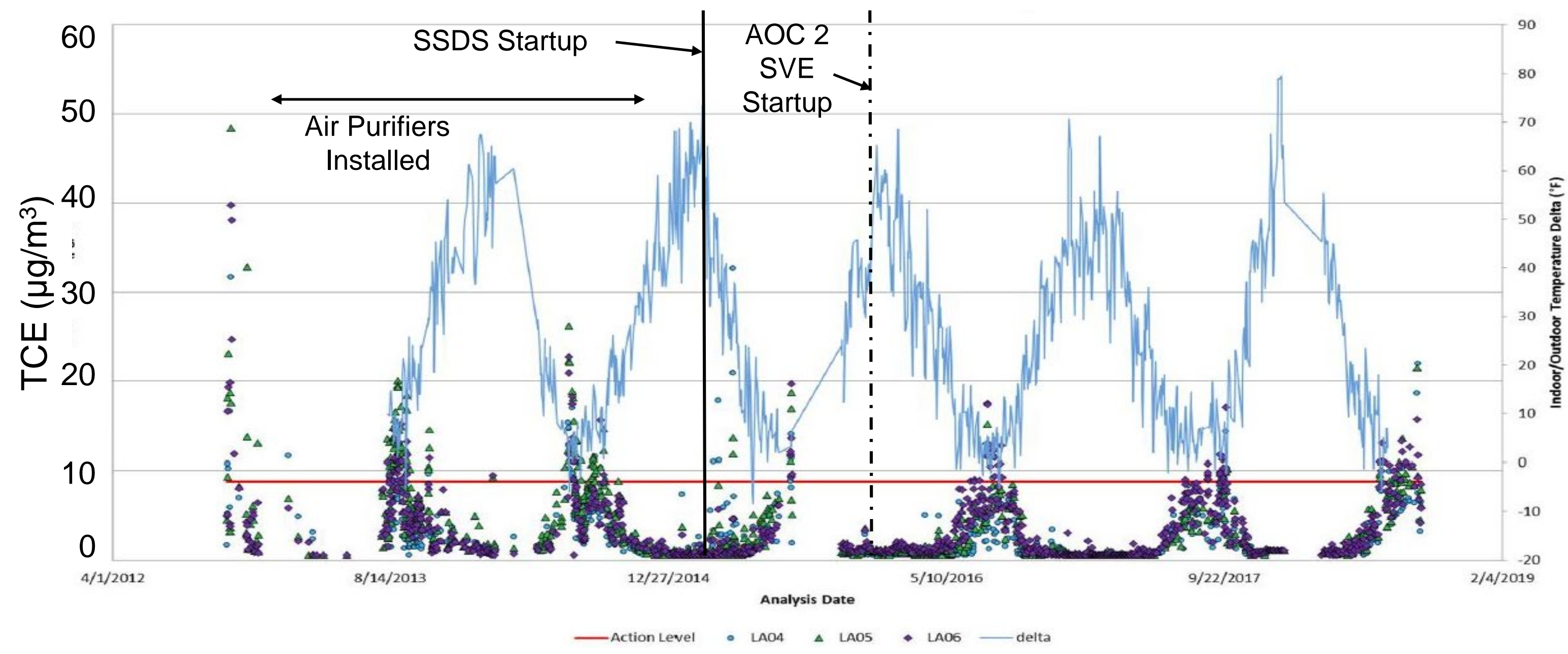

US Army Corps of Engineers • Engineer Research and Development Center UNCLASSIFIED

9 


\section{AOC 9 SVE Soil Monitoring}

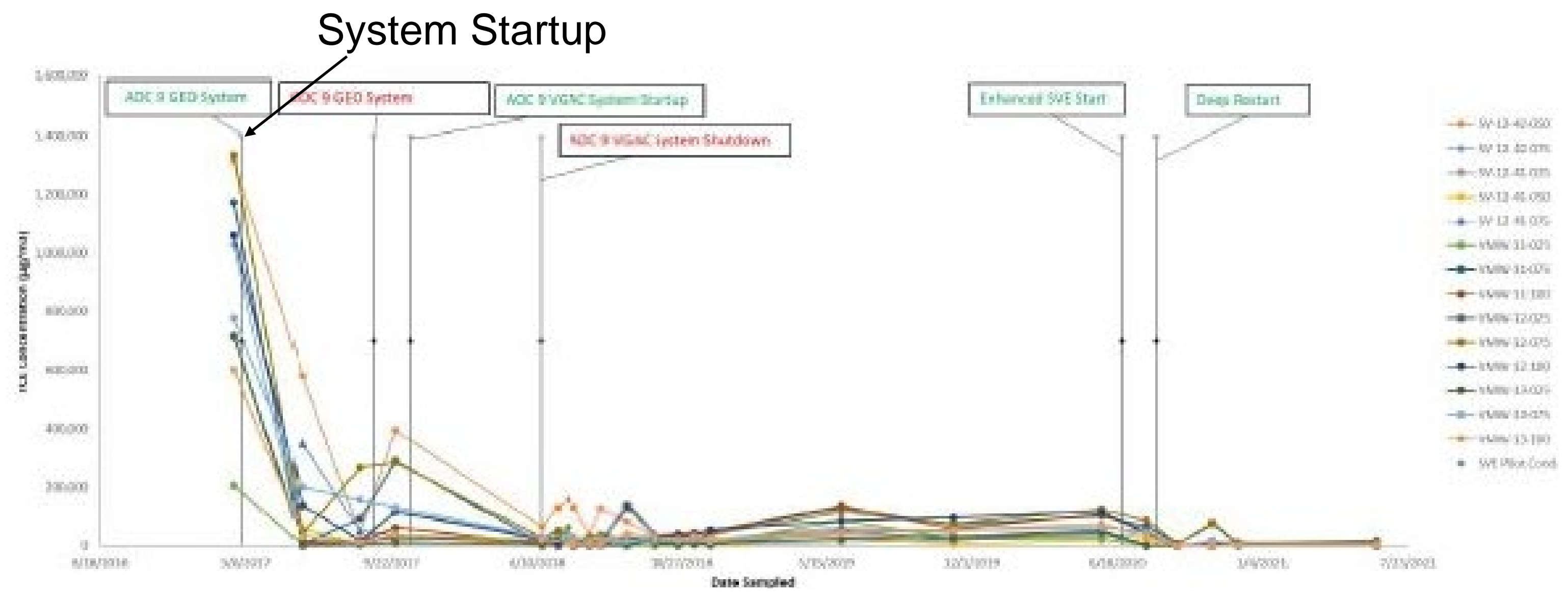




\section{TCE Levels Second Floor}

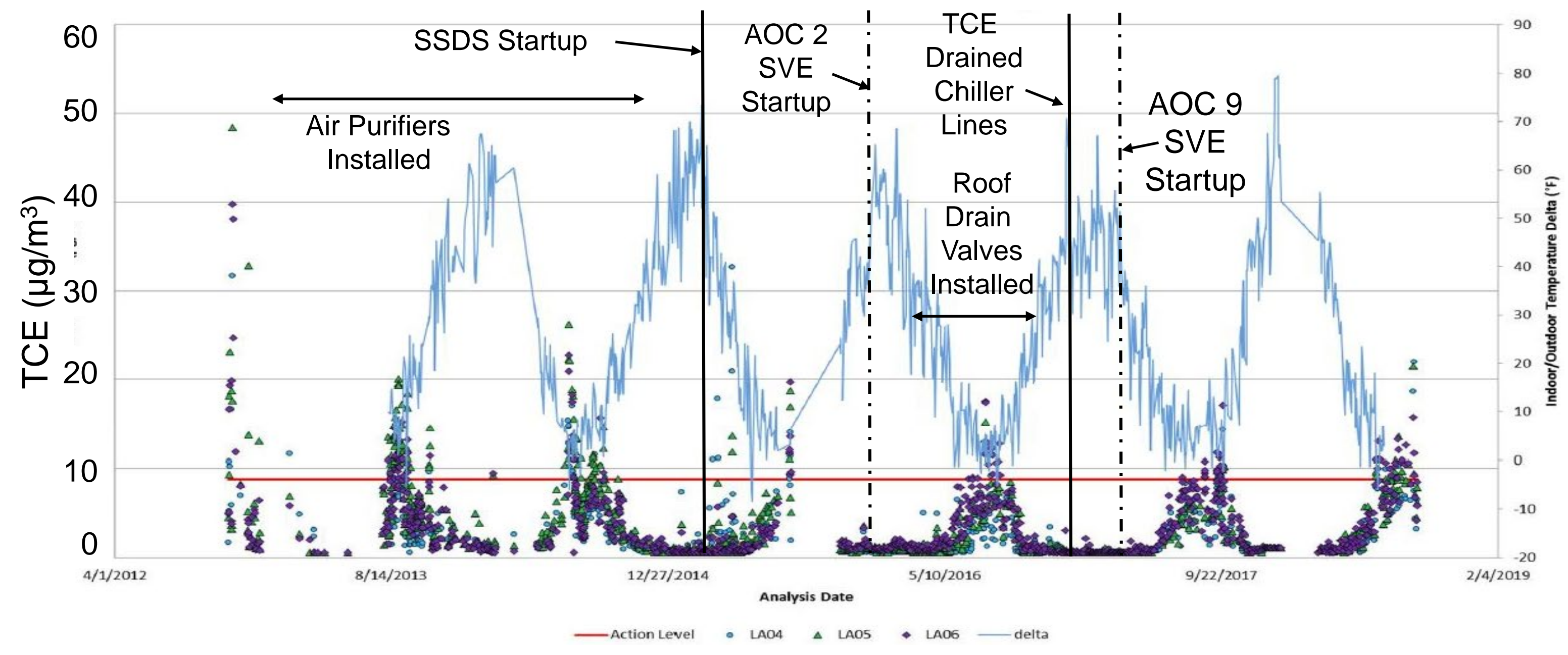




\section{Smoke Testing}
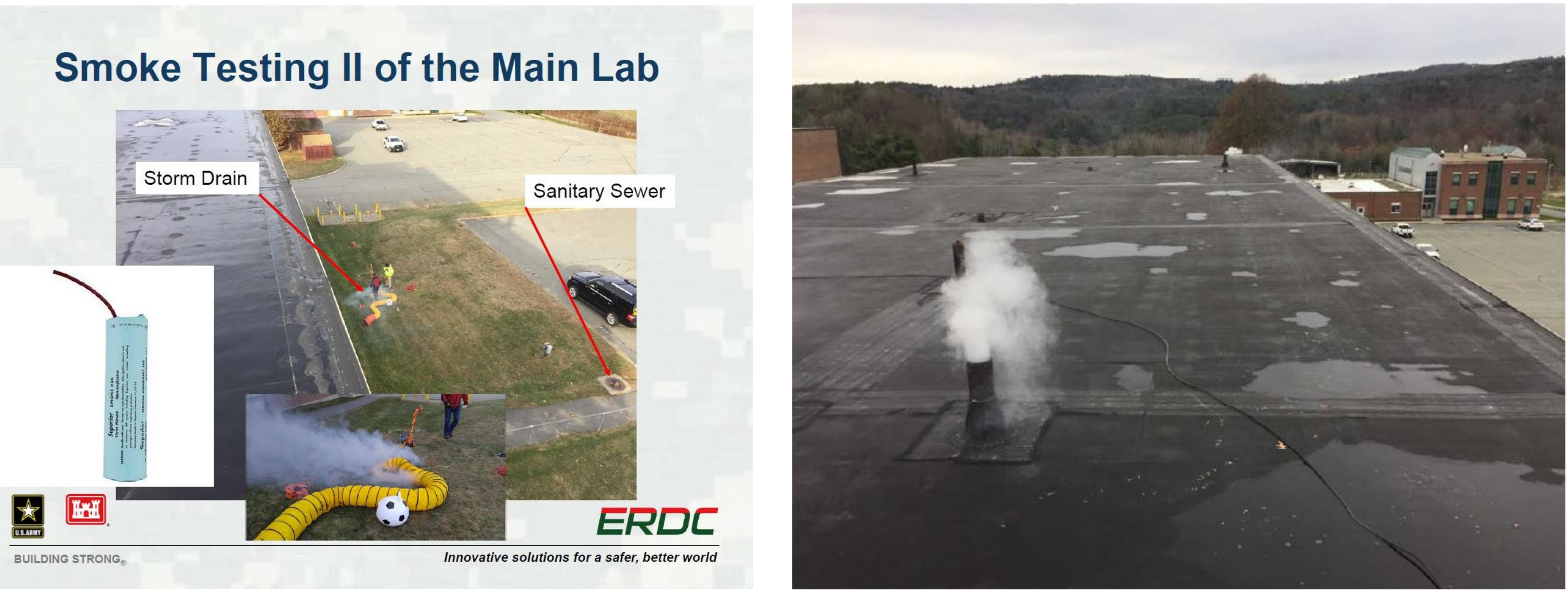


\section{Smoke Testing}

Toilet Seal

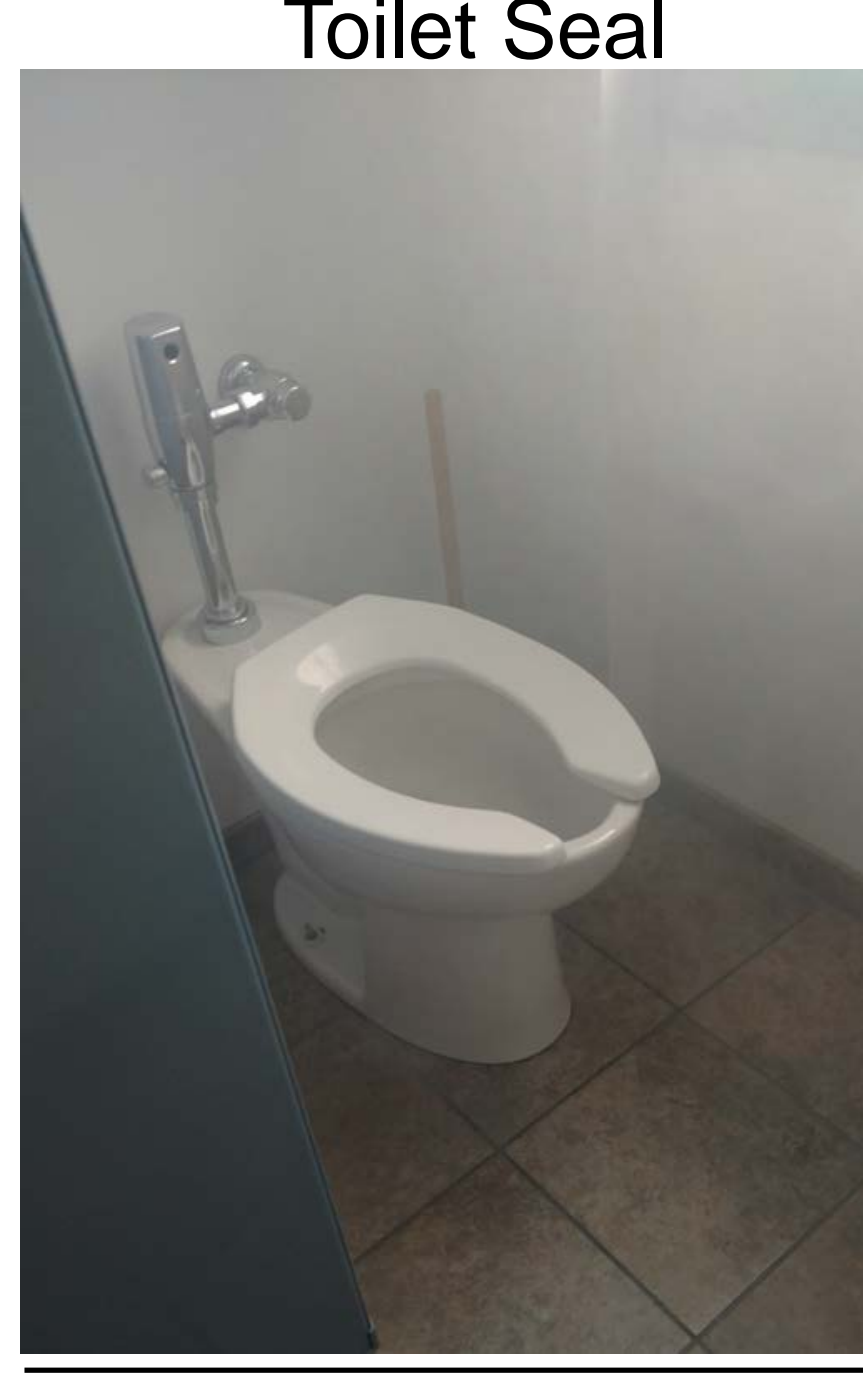

Sanitary Sewer Line Above Suspended Ceiling

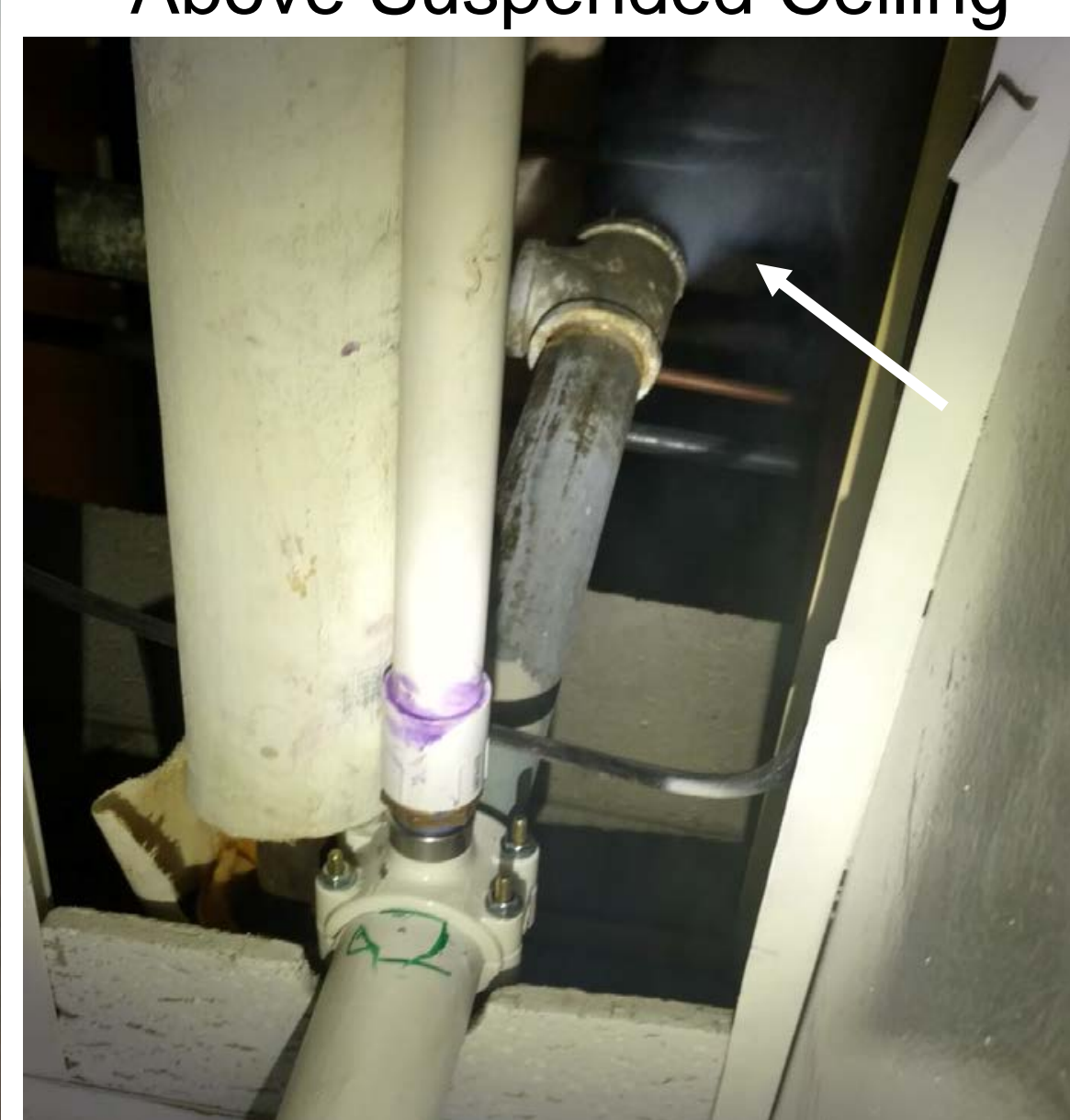

Open Pipe Beneath Raised Floor 


\section{TCE Levels Second Floor}

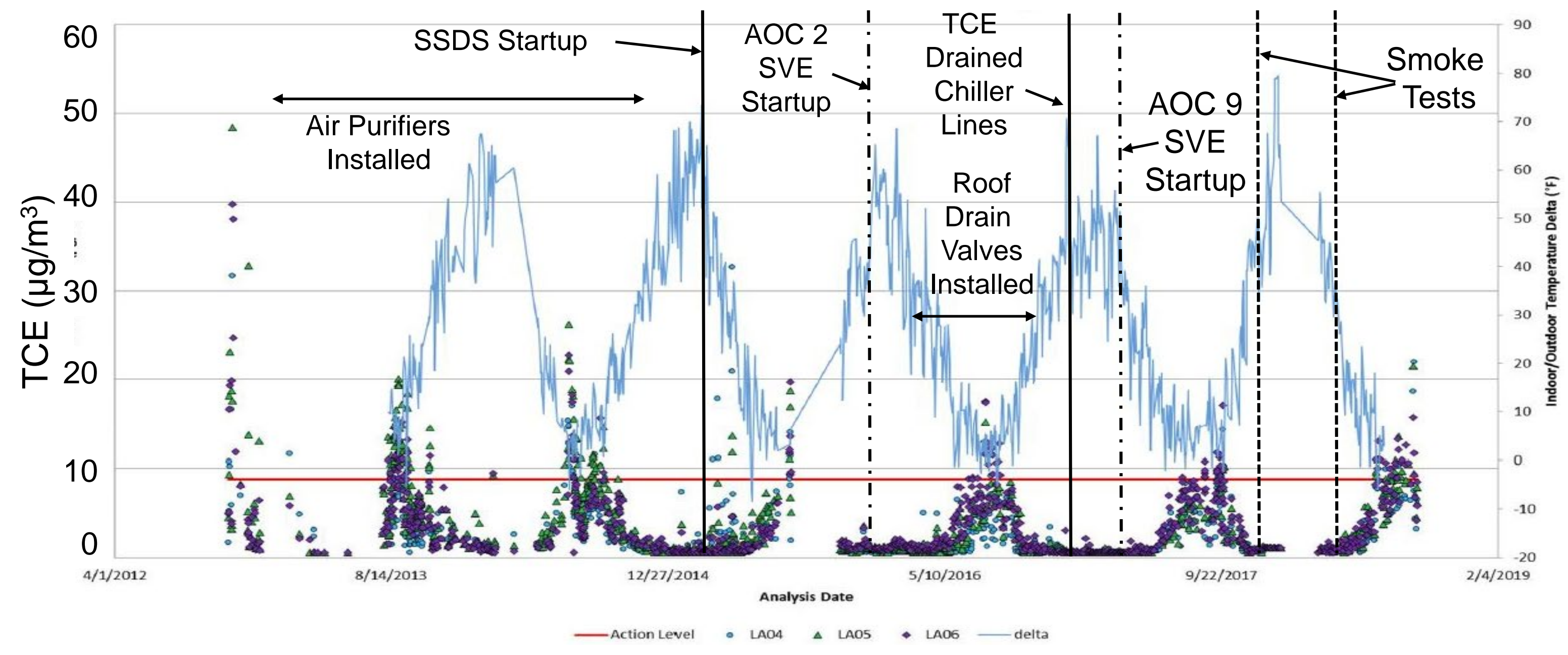




\section{Plenum TCE Levels}
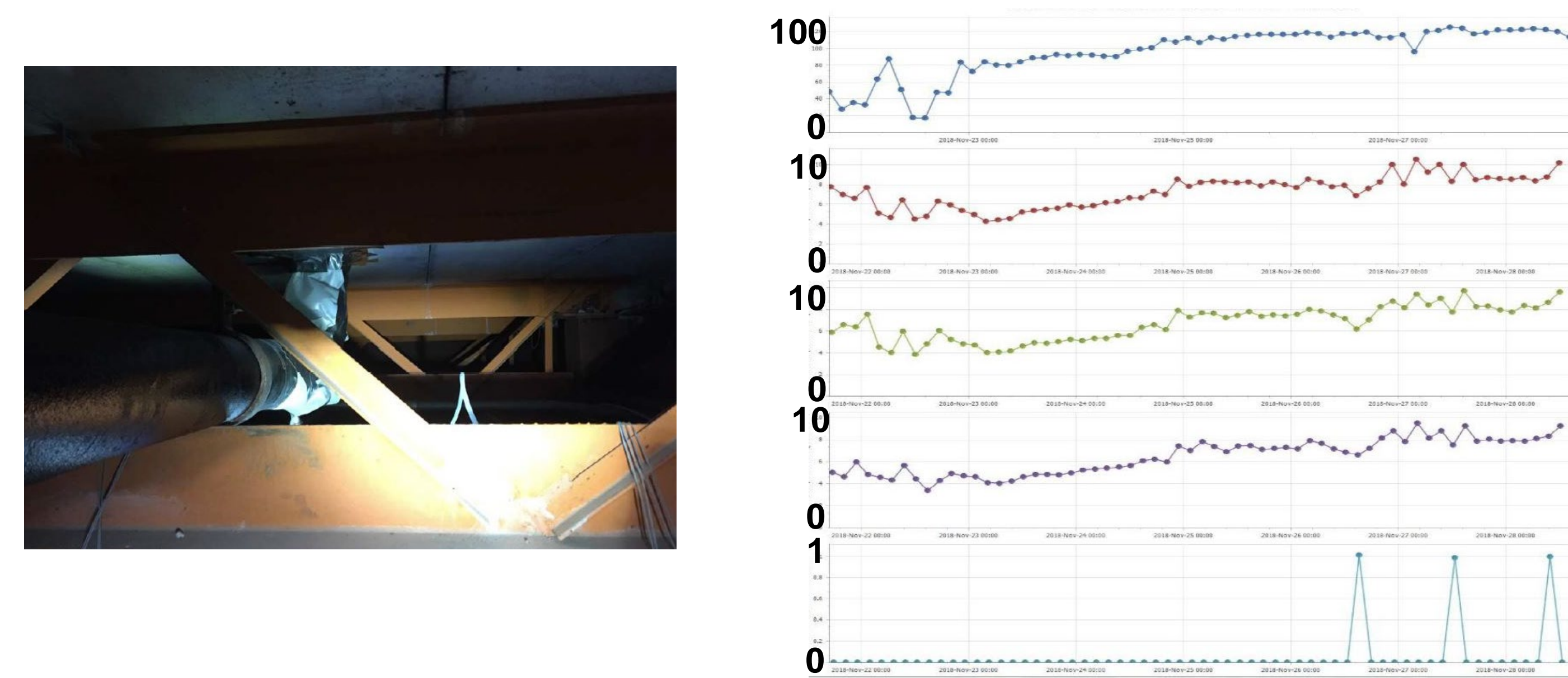

Under Rubber

Roof

High Plenum

Mid-Plenum

Low Plenum

RM 222

ERDC

a safer, better world 


\section{TCE Distribution in Plenum}

August 14, 2018 - PM

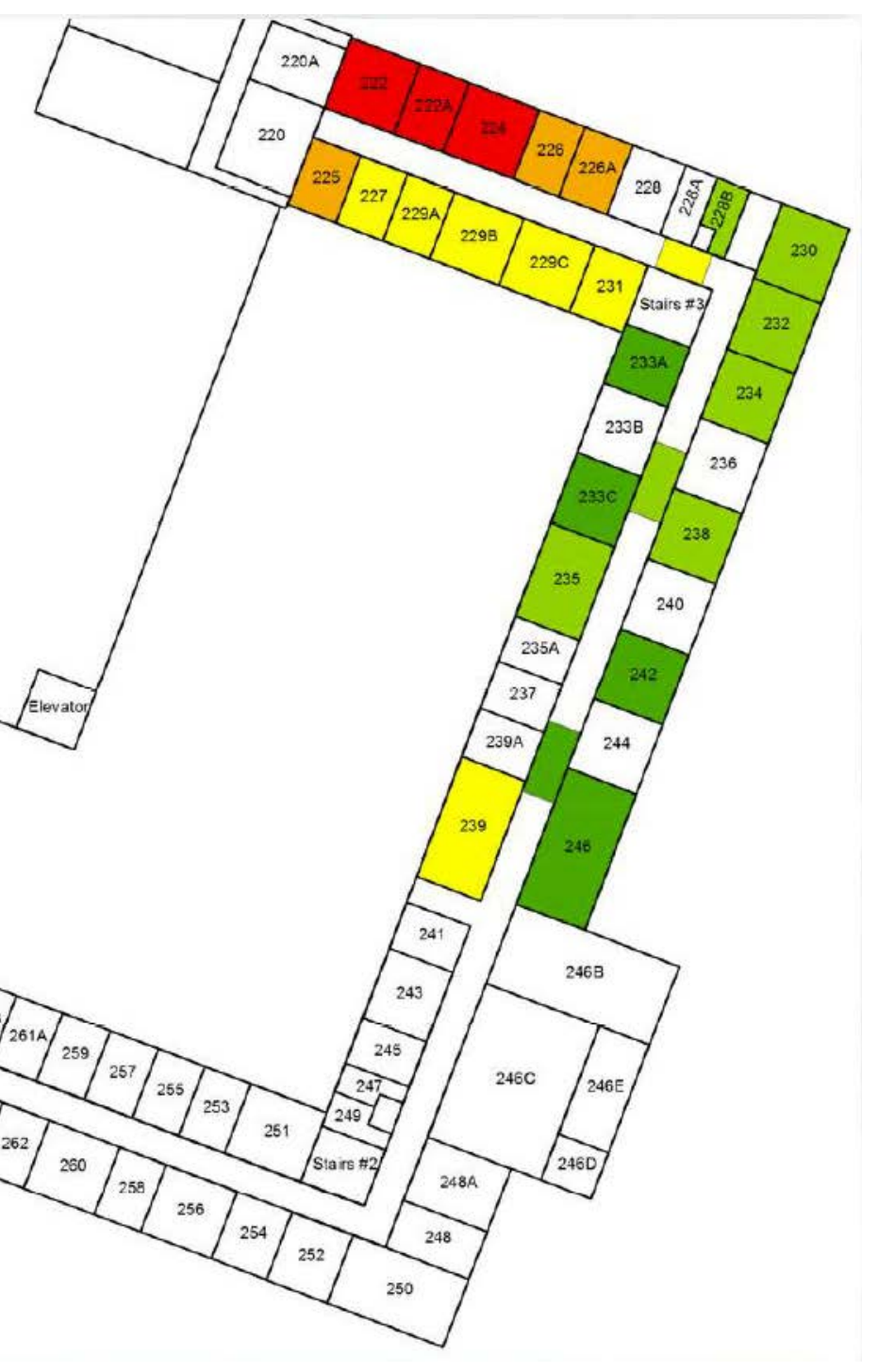




\section{TCE Distribution in Plenum}

August 15, 2018 - AM
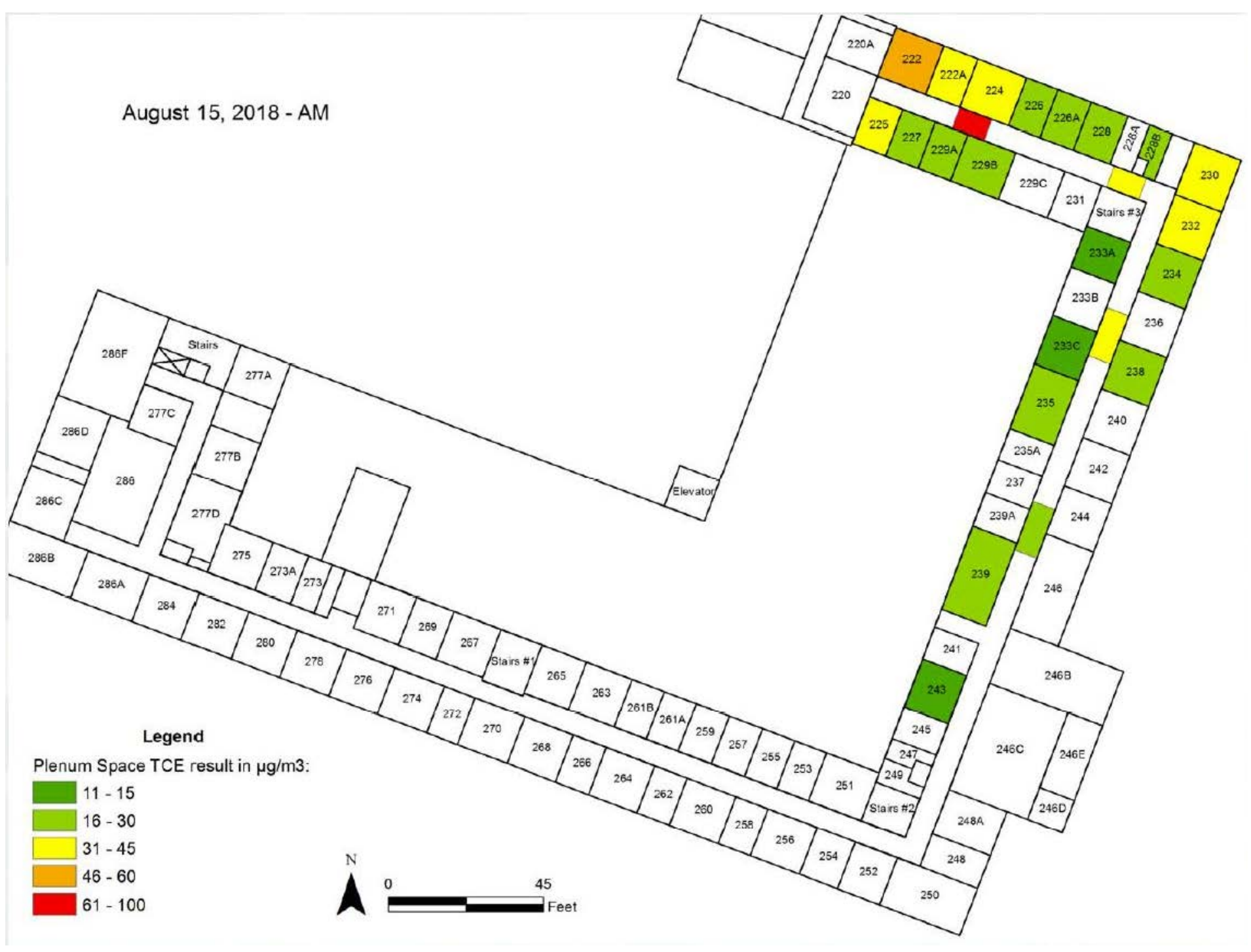


\section{TCE Distribution in Plenum}

August 15, 2018 - PM
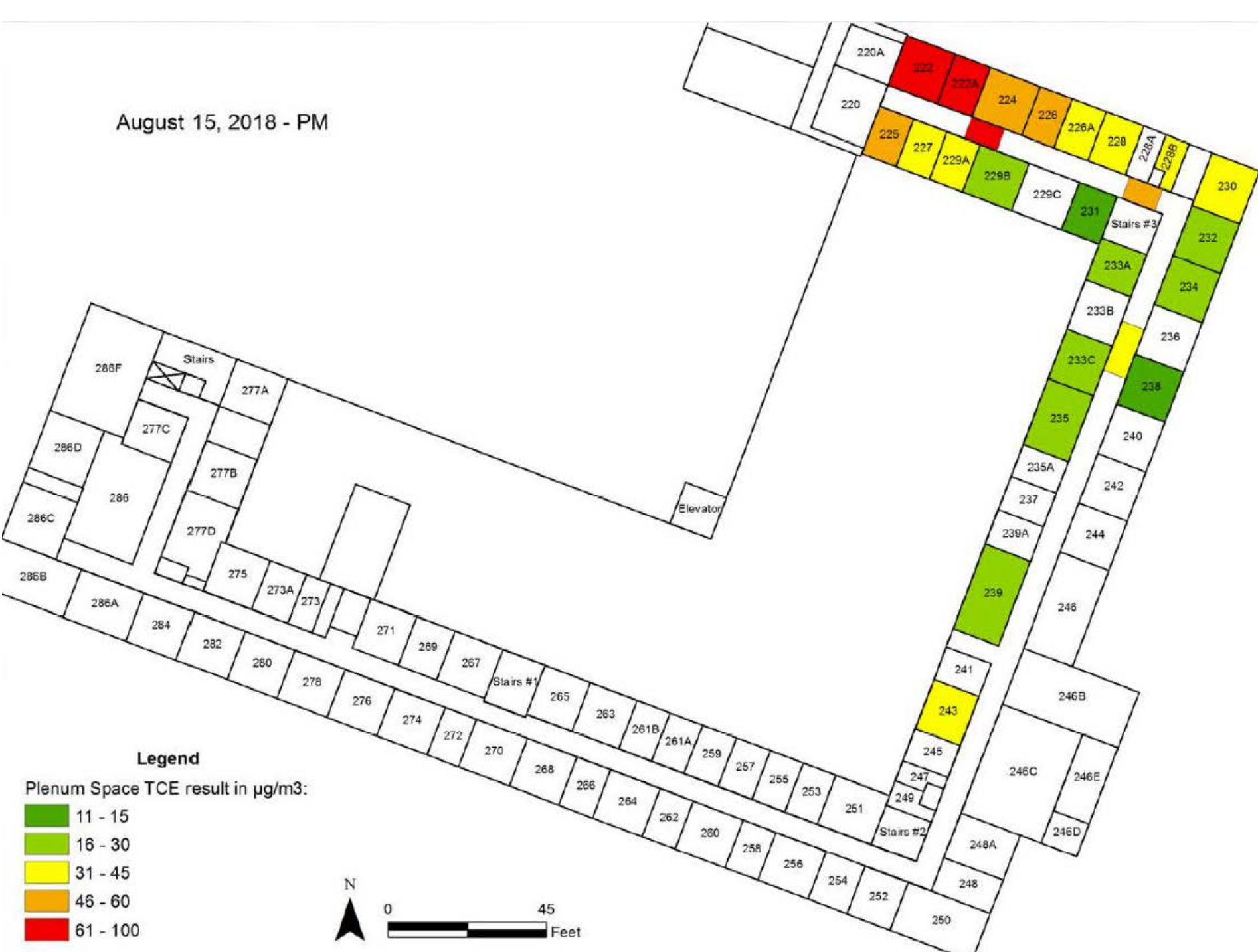

TCE result in $\mu \mathrm{g} / \mathrm{m} 3$

$31-45$

$61-100$

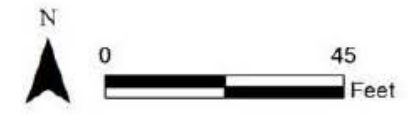




\section{TCE Distribution in Plenum}

$2^{\text {nd }}$ Floor Main Lab Plenum Sampling

August 22, 2018 - PM
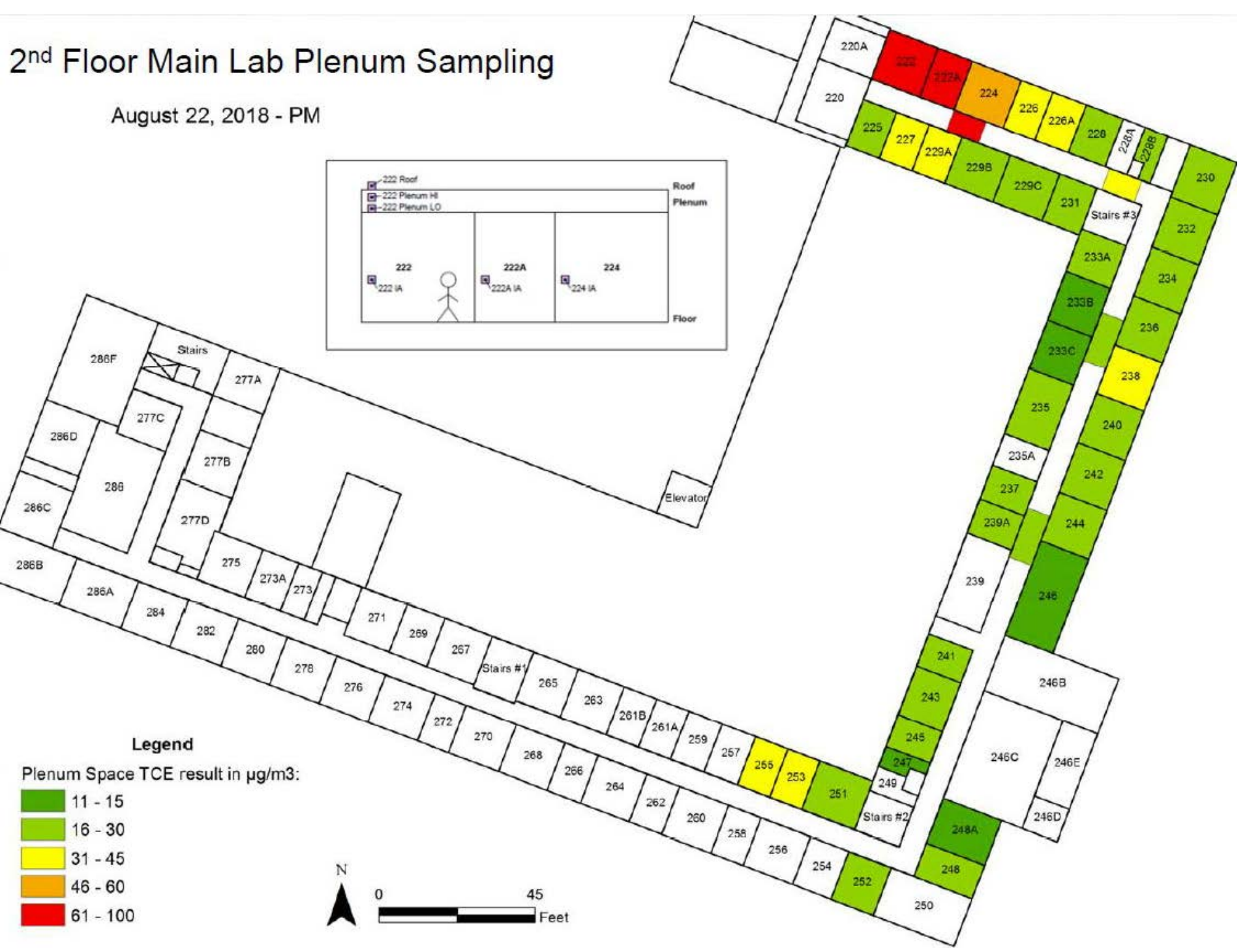

$11-15$

$16-30$
$31-45$

$46-60$
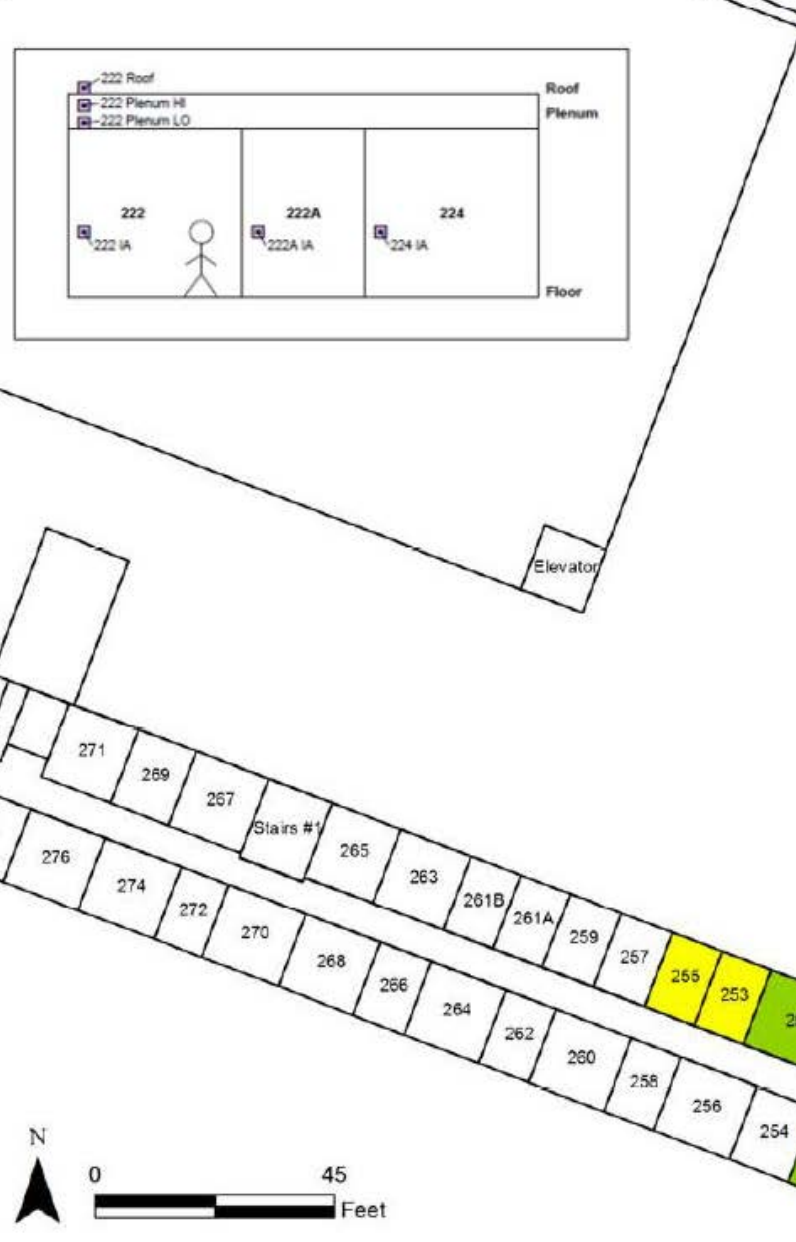

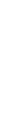




\section{Indoor Air Second Floor TCE Trends since Remediation}

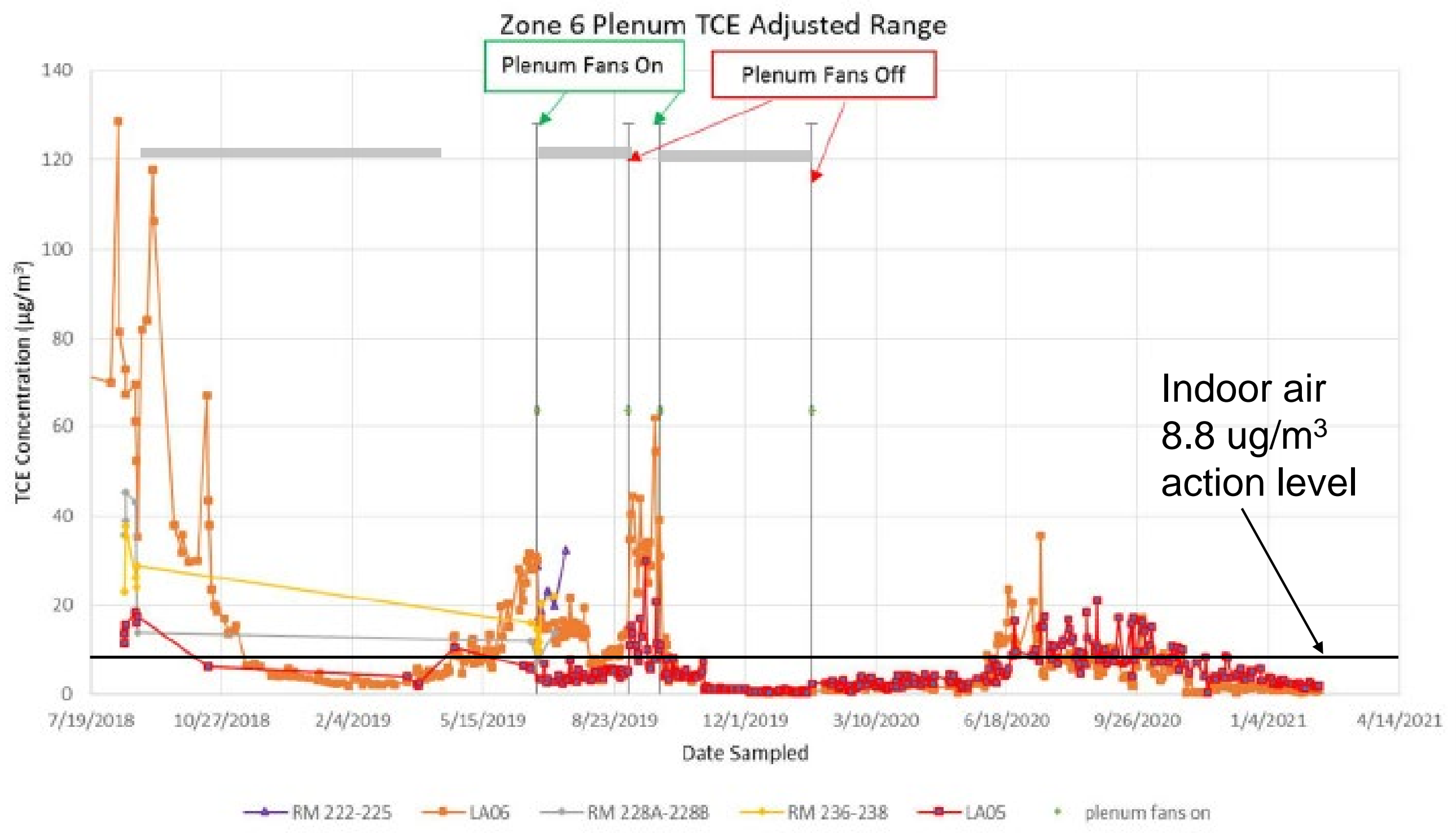




\section{Current Status}

- SSDS influent TCE levels below $880 \mathrm{ug} / \mathrm{m}^{3}$ regulatory guideline

- Subslab TCE vapor concentrations generally below $100,000 \mathrm{ug} / \mathrm{m}^{3}$

- No rebound of TCE observed at SVE pilot-test locations

- AOC 2 SVE - 3,000 kg TCE removed

- AOC 9 SVE - $600 \mathrm{~kg}$ TCE removed

- Periodic TCE fluctuations above action levels in second floor north wing offices in late Summer prior to 2019

- Sampling of roof materials in Spring 2019

- Installed carbon air purifiers in the plenum space early Summer 2019

- TCE concentrations in plenum space reduced and second floor offices (below action levels) since Fall 2020 


\section{Conclusions}

- Vapor emanations along utility lines (roof drains, sewer lines, refrigeration lines), elevator shaft, volatile back diffusion from building materials (concrete, insulation, roofing) and other sources are underestimated and being missed

- Periodic SUMA canister sampling is insufficient for assessing VI variability, determining exposure pathways, and quantifying exposure

- Extrapolation of VI pathways from residential studies to industrial sites is inappropriate and misleading

- Term VI should be all encompassing not only emanations through subslab but emanations from volatile back diffusion of building materials and subsurface preferential pathways (utility lines) 


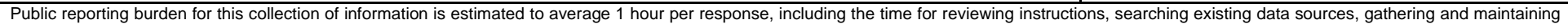

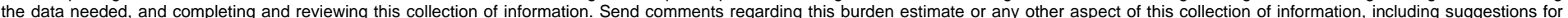

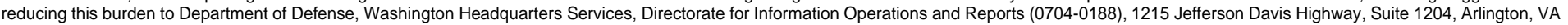

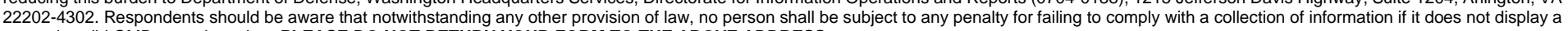
currently valid OMB control number. PLEASE DO NOT RETURN YOUR FORM TO THE ABOVE ADDRESS.
1. REPORT DATE (DD-MM-YYYY)
February 2022
Final

4. TITLE AND SUBTITLE

VI Preferential Pathways of a Large Government Building

3. DATES COVERED (From - To)

5a. CONTRACT NUMBER

5b. GRANT NUMBER

5c. PROGRAM ELEMENT NUMBER

6. AUTHOR(S)

Jay Clausen, D. Moore, K. Miller, and L. Haines-Ecklund

7. PERFORMING ORGANIZATION NAME(S) AND ADDRESS(ES)

See next page.

U.S. Army Environmental Command

2450 Connell Road

Fort Sam Houston, TX

5d. PROJECT NUMBER

5e. TASK NUMBER

5f. WORK UNIT NUMBER

8. PERFORMING ORGANIZATION REPORT NUMBER

ERDC/CRREL MP-22-4

10. SPONSOR/MONITOR'S ACRONYM(S)

11. SPONSOR/MONITOR'S REPORT NUMBER(S)

\section{DISTRIBUTION I AVAILABILITY STATEMENT}

Approved for public release; distribution is unlimited.

13. SUPPLEMENTARY NOTES

This information was originally presented at the Association for Environmental Health and Sciences Foundation (AEHS) virtual 37th

Annual International Conference on Soils, Sediments, Water, and Energy on 21 October 2021.

Funding was under MIPR Customer Order 11415853.

\section{ABSTRACT}

Trichloroethylene (TCE) releases from leaks and spills next to a large government building occurred over several decades with the most recent event occurring 20 years ago. In response to a perceived conventional vapor intrusion (VI) issue a sub-slab depressurization system (SSDS) was installed 6 years ago. The SSDS is operating within design limits and has achieved building TCE vapor concentration reductions. However, subsequent periodic TCE vapor spikes based on daily HAPSITE ${ }^{\mathrm{TM}}$ measurements indicate additional source(s).

Two rounds of smoke tests conducted in 2017 and 2018 involved introduction of smoke into a sanitary sewer and storm drain manholes located on effluent lines coming from the building until smoke was observed exiting system vents on the roof. Smoke testing revealed many leaks in both the storm sewer and sanitary sewer systems within the building. Sleuthing of the VI source term using a portable HAPSITETM indicate elevated vapor TCE levels correspond with observed smoke emanation from utility lines.

Sleuthing activities also found building roof materials explain some of the elevated TCE levels on the 2nd floor. Installation of an external blower in the roof truss space has greatly reduced TCE levels. Preferential VI pathways and unexpected source terms may be overlooked mechanisms as compared to conventional VI.

\section{SUBJECT TERMS}

Trichloroethylene, Indoor air pollution, Air quality management

\begin{tabular}{|c|c|c|c|c|c|}
\hline \multicolumn{3}{|c|}{ 16. SECURITY CLASSIFICATION OF: } & \multirow{2}{*}{$\begin{array}{l}\text { 17. LIMITATION } \\
\text { OF ABSTRACT } \\
\text { UU }\end{array}$} & \multirow{2}{*}{$\begin{array}{l}\text { 18. NUMBER } \\
\text { OF PAGES } \\
28\end{array}$} & \multirow{2}{*}{$\begin{array}{l}\text { 19a. NAME OF RESPONSIBLE } \\
\text { PERSON } \\
\begin{array}{l}\text { 19b. TELEPHONE NUMBER (include } \\
\text { area code) }\end{array}\end{array}$} \\
\hline $\begin{array}{l}\text { a. REPORT } \\
\text { Unclassified }\end{array}$ & $\begin{array}{l}\text { b. ABSTRACT } \\
\text { Unclassified }\end{array}$ & $\begin{array}{l}\text { c. THIS PAGE } \\
\text { Unclassified }\end{array}$ & & & \\
\hline
\end{tabular}


7. PERFORMING ORGANIZATION NAME(S) AND ADDRESS(ES)

Cold Regions Research and Engineering Laboratory

U.S. Army Engineer Research and Development Center

72 Lyme Road

Hanover, NH 03775

USACE New England District

Concord, MA 01742

U.S. Army Environmental Command

Fort Sam Houston, TX 78234 